\title{
Chronic cypermethrin exposure alters mouse embryonic stem cell growth kinetics, induces Phase II detoxification response and affects pluripotency and differentiation gene expression
}

\author{
Paola Rebuzzini, ${ }^{1}$ Cinzia Civello, ${ }^{1}$ Edouard Nantia Akono, ${ }^{2}$ Lorenzo Fassina,, 3 Maurizio Zuccotti, ${ }^{1,4}$ Silvia Garagna ${ }^{1,4}$ \\ ${ }^{1}$ Department of Biology and Biotechnology “Lazzaro Spallanzani”, University of Pavia, Italy \\ ${ }^{2}$ Department of Biochemistry, University of Bamenda, Bambili, Cameroon \\ ${ }^{3}$ Department of Electrical, Computer and Biomedical Engineering, University of Pavia, Italy \\ ${ }^{4}$ Centre for Health Technologies (C.H.T.), University of Pavia, Italy
}

\begin{abstract}
Worldwide uncontrolled use of synthetic pyrethroids contaminates water and soil leading to health hazards. Cypermethrin (CYP), the most used pyrethroid, induces detrimental effects on adults and embryos at different stages of development of several vertebrate species. In Mammals, CYP-induced alterations have been previously described in adult somatic cells and in post-implantation embryos. It remains unknown whether CYP has effects during pre-implantation development. Studies to access pre-implantation embryo toxicity are complicated by the restricted number of blastocysts that may be obtained, either in vivo or in vitro. Embryonic stem cells (ESCs) are an in vitro model study that overcomes these limitations, as millions of pluripotent cells are available to the analysis. Also, ESCs maintain the same pluripotency characteristics and differentiation capacity of the inner cell mass (ICM) present in the blastocyst, from which they derive. In this work, using mouse R1 ESCs, we studied CYP-induced cell death, ROS production, the activation of oxidative stress-related and detoxification responses and the population growth kinetics following $72 \mathrm{~h}$ exposure at the $0.3 \mathrm{mM} \mathrm{LD} \mathrm{D}_{50}$ dose. Also, the expression levels of pluripotency genes in exposed ESCs and of markers of the three germ layers after their differentiation into embryoid bodies (EBs) were determined. Two apoptotic waves were observed at 12$24 \mathrm{~h}$ and at $72 \mathrm{~h}$. The increase of ROS production, at $24 \mathrm{~h}$ until the end of the culture period, was accompanied by the induction, at $48 \mathrm{~h}$, of redox-related Cat, Sod1, Sod2, Gpx1 and Gpx4 genes. Up-regulation of Cyp1b1, but not of Cyp1a1, phase I gene was detected at $72 \mathrm{~h}$ and induction of Nqo1, Gstal and Ugt1a6 phase II genes began at $24 \mathrm{~h}$ exposure. The results show that exposed R1 ESCs activate oxidative stress-related and detoxification responses, although not sufficient, during the culture period tested, to warrant recovery of the growth rate observed in untreated cells. Also, CYP exposure altered the expression of Oct-4 and Nanog pluripotency genes in ESCs and, when differentiated into EBs, the expression of Fgf5, Brachyury and Foxa2, early markers of the ectoderm, mesoderm and endoderm germ layers, respectively. NIH/3T3 cells, a differentiated cell line of embryonic origin, were used for comparison.
\end{abstract}

Key words: Cypermethrin; embryonic stem cells; cell growth; apoptosis; reactive oxygen species; detoxification response.

Correspondence: Silvia Garagna, Laboratorio di Biologia dello Sviluppo, Dipartimento di Biologia e Biotecnologie "Lazzaro Spallanzani”, Università degli Studi di Pavia, Via Ferrata 9, 27100 Pavia, Italy. Tel. +39.0382.986323 - Fax: +39.0382.986270. E-mail: silvia.garagna@unipv.it

Contributions: PR, contribution to design experiments, data acquisition, manuscript drafting and critical revision; CC, ENA, data acquisition, manuscript drafting; LF, data elaboration; MZ, manuscript critical revision; SG, contribution to design experiments and manuscript critical revision. All authors read and approved the final manuscript.

Conflict of interest: The authors declare that there are no conflicts of interest.

Availability of data and materials: The data used to support the findings of this study are available from the corresponding author upon request. 


\section{Introduction}

Synthetic pyrethroids are the most worldwide diffused pesticides, largely used since the ' $80 \mathrm{~s}$ in households and agriculture ${ }^{1}$ because of their effectiveness and low toxicity compared to other insecticides, such as organophosphorus and carbamic ester compounds. ${ }^{2,3}$ As a result of their diffusion and uncontrolled use, pyrethroids, by contaminating water and soil, have entered the food chain ${ }^{3,4-7}$ becoming a serious human health hazard. ${ }^{8}$ Cypermethrin (CYP), a type II pyrethroid insecticide, classified by the World Health Organization as moderately hazardous (class II), is the most widely used against a broad range of insects. ${ }^{9-11}$

CYP detrimental effects have been described on adults and during embryonic development of several vertebrate species. Specifically, earlier studies demonstrated that CYP generates oxidative stress and apoptosis in fish liver, ${ }^{12-14}$ retina, ${ }^{15}$ kidney ${ }^{12}$ and gill, ${ }^{16}$ rat brain and liver ${ }^{17}$ cells and also in mouse macrophages. ${ }^{18}$ In the mouse, by impairing endometrial receptivity, CYP severely reduces embryo implantation. ${ }^{19}$

It remains however unknown whether CYP has effects during pre-implantation, a developmental window with three main critical steps. The first occurs at the time of embryonic genome activation (2-cell or 4-cell stage in mouse and human, respectively) ${ }^{20}$, the second when the embryo reaches the morula stage, ${ }^{20}$ followed by the most critical at the blastocyst stage, when, in our species, the great majority of embryos is lost. ${ }^{21}$ Pre-implantation embryonic loss is either a consequence of a functional damage to the endometrium or to the cell lines that make up the blastocyst, i.e., the trophectoderm or the inner cell mass (ICM), which will contribute, respectively, to the extra-embryonic tissue (e.g., placenta) or to the foetus. A damage to the ICM cells, when not selective against the embryo, could, however, cause serious damage to the foetus or appear much later in development, childhood or adulthood.

Despite the blastocyst being one of the most vulnerable developmental stage in the life of a new individual, studies to access the embryo-toxicity of test substances, performed on model animals, are complicated by the required experimental setting and the restricted number of blastocysts that may be obtained, either in vivo or in vitro, for each single experiment. To this regard, embryonic stem cells (ESCs) are an in vitro model study that overcomes these limitations, as for each experiment millions of pluripotent cells are available to the analysis of the test substance. ESCs maintain the same pluripotency characteristics and differentiation capacity of the ICM from which they derive. ${ }^{22-24}$

In this work, using mouse ESCs (mESCs) as an in vitro model of the blastocyst's ICM, we studied CYP-induced alterations that, in Mammals, have been previously described in adult somatic cells and in post-implantation embryos. Specifically, cell growth, cell death, ROS production and the activation of a detoxification response were analysed in mESCs and NIH/3T3 cells, the latter, a differentiated cell line of embryonic origin, used for comparison. Also, the differentiation potential of exposed mESCs was determined through their development into embryoid bodies (EBs).

\section{Materials and Methods}

\section{Cells and cell cultures}

The R1 mESC line (kindly provided by Dr. Nagy from Samuel Lunenfeld Research Institute, Mount Sinai Hospital, Toronto, Ontario, Canada) was cultivated as reported in Rebuzzini et al. ${ }^{25}$ Briefly, cells were grown in Knockout DMEM supplemented with 15\% ESC Qualified FBS (Thermo Fisher Scientific, Waltham,
MA, USA), $2 \mathrm{mM}$ L-glutamine, $1 \mathrm{x}$ non-essential amino acids, $0.5 \%$ penicillin/streptomycin (all from Life Technology, Carlsbad, CA, USA), $0.1 \mathrm{mM} \beta$-mercaptoethanol (Sigma-Aldrich, St. Louis, MO, USA) and $500 \mathrm{U} / \mathrm{ml}$ ESGRO-LIF (Millipore, Burlington, MA, USA). The STO cell line (American Type Culture Collection CRL-2225), used as feeder-layer, was maintained in DMEM (Sigma-Aldrich) supplemented with $10 \%$ FBS, $4 \mathrm{mM}$ L-glutamine, $1 \mathrm{x}$ non-essential amino acids, $0.5 \%$ penicillin/streptomycin (all from Life Technology), $0.1 \mathrm{mM} \beta$-mercaptoethanol (Sigma-Aldrich) and $0.2 \mathrm{mg} / \mathrm{mL}$ geneticin (Sigma-Aldrich).

Cells were routinely passaged with $0.25 \%$ trypsin every $2-3$ days, alternating a passage on STO feeder cells with two passages on gelatin-coated $100 \times 20 \mathrm{~mm}$ Petri dishes.

The NIH/3T3 cell line, hereafter 3T3 (a generous gift by Prof. Giulotto, Department of Biology and Biotechnology, University of Pavia), was cultured in DMEM (Sigma-Aldrich) supplemented with 10\% FBS, $4 \mathrm{mM}$ L-glutamine, 1x non-essential amino acids, $0.5 \%$ penicillin/streptomycin (all from Life Technology) and 0.1 $\mathrm{mM} \beta$-mercaptoethanol (Sigma-Aldrich). Cells were routinely passaged with $0.25 \%$ trypsin every $2-3$ days.

\section{Cypermethrin preparation}

$\alpha$-cypermethrin [ $\alpha$-Cyano-(3-phenoxyphenyl)-methyl 3-(2,2dichlorovinyl)-2,2-dimethyl cyclopropane carboxylate] (Abcam, Cambridge, UK) was dissolved to a final concentration of $100 \mathrm{mM}$ in dimethyl sulfoxide (DMSO). The solution was maintained at $-20^{\circ} \mathrm{C}$ and renewed every 7 days, to ensure the stability of the molecule, according to manufacturer instructions.

\section{Determination of CYP $\mathrm{LD}_{50}$ dose}

CYP toxicity was carried out by measuring the alteration of growth of a massive cell culture, as described by Rebuzzini et al. ${ }^{26}$ Briefly, $3 \times 10^{4} \mathrm{R} 1$ and $3 \mathrm{~T} 3$ cells were seeded in $6 \mathrm{~cm}$ Petri dish (Corning) and exposed to increasing concentrations of CYP $(0.01$, $0.05,0.1,0.2,0.4,0.6,0.8$ or $1 \mathrm{mM}$ ) or to $0.01 \%$ DMSO (Control, CTR). After $72 \mathrm{~h}$, the cells were collected in PBS 1x, pelleted at $1200 \mathrm{rpm}$ for $8 \mathrm{~min}$, lysed in $0.1 \mathrm{M} \mathrm{NaOH}$ and incubated at $50^{\circ} \mathrm{C}$ in water bath for $30 \mathrm{~min}$. The number of cells was estimated by measuring the absorbance of the lysate at $260 \mathrm{~nm}$.

\section{Cell growth curve determination}

R1 and 3 T3 cells were seeded at a density of $5 \times 10^{4}$ and $8 \times 10^{4}$, respectively, and incubated with the determined CYP $\mathrm{LD}_{50}$ concentration for $72 \mathrm{~h}$. Cells were harvested after 8, 24, 48 and $72 \mathrm{~h}$, and counted using a Bürker chamber.

\section{Apoptosis Annexin V assay}

The ApopNexin ${ }^{\mathrm{TM}}$ FITC and propidium iodide (PI) kit assay (Merck Millipore) was used to detect apoptosis after CYP treatment. Briefly, $3 \mathrm{~T} 3\left(1.5 \times 10^{4}\right.$ cells $)$ and R1 $\left(10^{5}\right.$ cells $)$ were seeded in $6 \mathrm{~cm}$ Petri dishes and exposed to $0.6 \mathrm{mM}$ and $0.3 \mathrm{mM} \mathrm{CYP}$, respectively, for 8 (only 3T3), 12 (only R1), 24, 48 and 72 h. Cells were harvested according to the manufacturer instructions and analysed, after staining, by bivariate flow cytometry [FITC band in FL1 and PI band in the FL3 channel, flow cytometer FACS Lyric BD (BD Biosciences, Franklin Lakes, NJ, USA)]. A minimum of 50,000 events was acquired for each sample. Data were processed, plotted and analysed using the BD FACSuite ${ }^{\mathrm{TM}}$ flow cytometer software.

\section{Reactive oxygen species quantification}

The cell-permeant 2',7'-dichlorodihydrofluorescein diacetate $\left(\mathrm{H}_{2} \mathrm{DCFDA}\right)$ fluorescent probe (Thermo Fisher Scientific) was used to evaluate the intracellular levels of ROS. R1 ( $10^{5}$ cells) and fibroblast $3 \mathrm{~T} 3\left(2 \times 10^{5}\right.$ cells $)$ were seeded in $10 \mathrm{~cm}$ Petri dishes and 
exposed to $0.3 \mathrm{mM}$ or $0.6 \mathrm{mM} \mathrm{CYP}$, respectively, for 8 (3T3 only), 12 (R1 only), 24, 48 and $72 \mathrm{~h}$ (both cell lines). Then, cells were collected, centrifuged at $500 \mathrm{rpm}$ for $5 \mathrm{~min}$ and resuspended in $1 \mathrm{x}$ PBS solution containing $10 \mu \mathrm{M} \mathrm{H}_{2}$ DCFDA. The mixture was incubated at $37^{\circ} \mathrm{C}$ for $30 \mathrm{~min}$ under dark conditions. The analyses of the samples were performed using a flow cytometer FACS Lyric BD (BD Biosciences). A minimum of 50,000 events were acquired for each sample. Data were processed, plotted and analysed using the BD FACSuite ${ }^{\mathrm{TM}}$ flow cytometer software.

\section{Cell cycle analysis}

R1 ( $10^{5}$ cells) and fibroblast 3 T3 $\left(2 \times 10^{5}\right.$ cells $)$ were seeded in $10 \mathrm{~cm}$ Petri dishes and exposed to $0.3 \mathrm{mM}$ and $0.6 \mathrm{mM} \mathrm{CYP}$, respectively. After 8 (3T3), 12 (R1), 24, 48 and $72 \mathrm{~h}$, the cells were harvested, washed in 1x PBS and stained with $1.5 \mathrm{ml}$ of $50 \mu \mathrm{g} / \mathrm{ml}$ propidium iodide $(\mathrm{PI})$, containing $100 \mathrm{U} / \mathrm{ml}$ of RNase and $0.05 \%$ Igepal (Sigma-Aldrich).

The analyses of the samples were performed using a flow cytometer FACS Lyric BD (BD Biosciences). A minimum of 50,000 events were acquired for each sample. Data were processed, plotted and analysed using the BD FACSuite ${ }^{\mathrm{TM}}$ flow cytometer software.

\section{Embryoid bodies formation}

CTR and CYP-exposed ESCs were differentiated into EBs, following culture in the absence of LIF, using the hanging drop protocol. ${ }^{27}$ After 3 days of culture, EBs were transferred into a 100 mm $0.1 \%$ agarose-coated Petri dish (Corning); after 2 more days, RNA was collected from about 100 EBs.

\section{RNA extraction, reverse transcription and real-time PCR}

Total RNA was extracted from R1 (10 cells) and 3 T3 $\left(2 \times 10^{5}\right.$ cells) cells after 8 (3T3), 12 (R1), 24, 48 and $72 \mathrm{~h}$ of CYP exposure and from EBs at the end of the differentiation period (5 days), using GenElute Mammalian Total RNA kit (Sigma-Aldrich) according to the manufacturer's instructions. Reverse transcription was performed in a final volume of $20 \mu 1$ reaction mixture containing $1 \mu \mathrm{g}$ of RNA, 1x PCR buffer, $5 \mathrm{mM} \mathrm{MgCl} 2,4 \mathrm{mM}$ of each dNTP, $0.625 \mu \mathrm{M}$ oligo d(T) $)_{16}, 1.875 \mu \mathrm{M}$ Random Hexamers, $20 \mathrm{U}$ RNAse inhibitor and $50 \mathrm{U}$ MuLV reverse transcriptase (Thermo Fisher Scientific). The amplification programme was as follows: $25^{\circ} \mathrm{C}$ for $10 \mathrm{~s}, 42^{\circ} \mathrm{C}$ for $15 \mathrm{~s}, 99^{\circ} \mathrm{C}$ for $5 \mathrm{~s}$.

One twentieth of the resulting cDNA was amplified in duplicate by real-time PCR in $20 \mu \mathrm{L}$ reaction mixture with $200 \mathrm{nM}$ of each primer (designed with Primer 3 software; Supplementary Table 1) and MESA GREEN qPCR MasterMix Plus for SYBR assay no ROX sample (Eurogentec, Liege, Belgium) at $1 \mathrm{x}$ as final concentration. The amplification reaction, performed in a Rotorgene 6000 (Corbett Life Science, Sydney, Australia), for the analysis of catalase (Cat), superoxide dismutase 1 and 2 ( $\operatorname{Sod} 1$, Sod2), glutathione peroxidase 1 and 4 (Gpxl, Gpx4), cytochrome 1a1 (Cypla1), octamer-binding transcription factor 4 (Oct-4), homeobox protein NANOG (Nanog), T-Box Transcription Factor $\mathrm{T}$ (Brachyury), fibroblast growth factor $5(F g f 5)$ and forkhead box protein A2 (Foxa2) transcripts expression was as follows: $95^{\circ} \mathrm{C}$ for $5 \mathrm{~min}$, followed by 40 cycles at $95^{\circ} \mathrm{C}$ for $10 \mathrm{~s}, 60^{\circ} \mathrm{C}$ for $15 \mathrm{~s}$, $72^{\circ} \mathrm{C}$ for $20 \mathrm{~s}$. The amplification reaction for the analysis of cytochrome 1b1 (Cyplb1), NAD(P)H quinone dehydrogenase (Nqol), glutathione S-transferase alpha 1 (Gstal) and UDP-glucuronosyltransferase 1 a 6 (Ugtlab) transcripts expression was as follows: $95^{\circ} \mathrm{C}$ for $5 \mathrm{~min}$, followed by 40 cycles at $95^{\circ} \mathrm{C}$ for $15 \mathrm{~s}$, $60^{\circ} \mathrm{C}$ for $20 \mathrm{~s}, 72^{\circ} \mathrm{C}$ for $60 \mathrm{~s}$.

The Rotorgene 6000 Series Software 1.7 was used for the comparative concentration analysis. $\beta$-2-microglobulin $(\beta 2 \mathrm{~m})$ gene expression was used for sample normalization. ${ }^{28}$

\section{Statistical analysis}

For each assay, three independent experiments were performed. The results were analysed using SigmaStat software. Data, expressed as mean $\pm \mathrm{SD}$, were analysed by the one-way ANOVA and by the post-hoc LSD test.

\section{Results}

We first determined the CYP dose that reduced growth of $50 \%$ $\left(\mathrm{LD}_{50}\right)$; the $\mathrm{LD}_{50}$ was $0.3 \mathrm{mM}$ and $0.6 \mathrm{mM}$, for mouse R1 ESCs (R1) and 3T3, respectively (Supplementary Figure 1); all the experiments described below were performed at these specific doses. The presence of the DMSO vehicle did not significantly alter cell growth of both cell lines $(\mathrm{P}>0.05)$ (data not shown).

\section{Cell growth kinetics}

$\mathrm{R} 1$ and $3 \mathrm{~T} 3$ cell lines displayed different growth dynamics. A significant $(\mathrm{P}<0.003)$ decrease of the $\mathrm{R} 1$ cell number was observed up to $24 \mathrm{~h}$ following CYP exposure (Figure 1). Then, exposed cells grew, although at lower rate compared to CTR, as evidenced by the
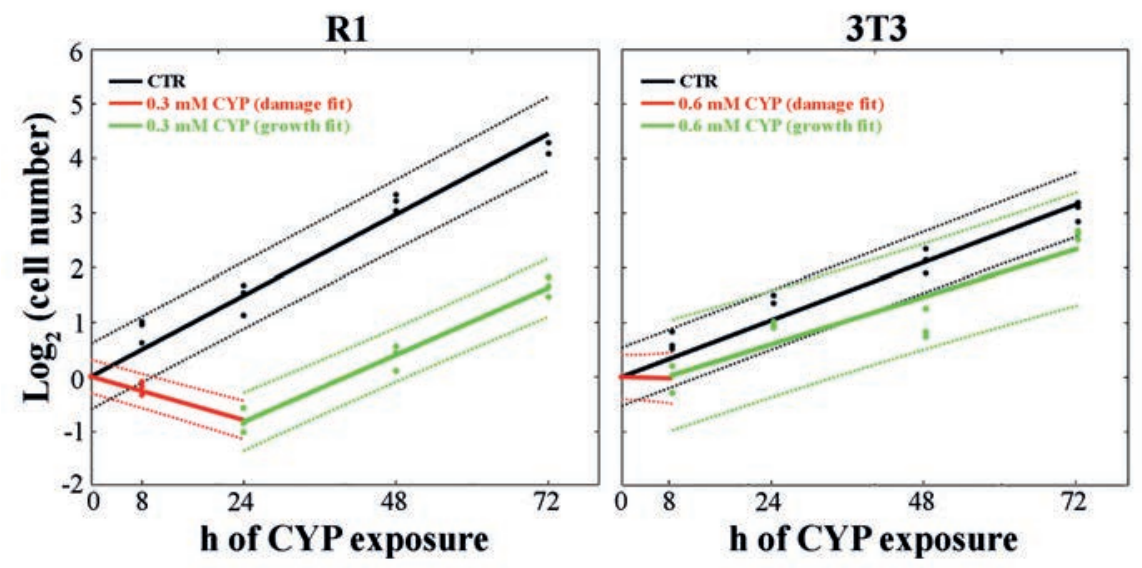

Figure 1. Fitted growth curves of CTR and CYP-exposed cells of R1 and 3T3 lines. Circles represent the experimental data; dotted lines are the upper and lower percentage bounds $(95 \%)$. 
significant reduction ( $\mathrm{P}=0.008)$ of the regression slope (Figure 1); the population doubling (PD) time was higher in exposed (19.52 h) compared to that of CTR $(16.21 \mathrm{~h}$, as also shown earlier by Tamm et al. ${ }^{29}$ ) cells. In $3 \mathrm{~T} 3$, the number of exposed cells significantly decreased $(\mathrm{P}=0.024)$, compared to $\mathrm{CTR}$, within $8 \mathrm{~h}$ of culture (Figure 1). Then, CTR and treated 3T3 cells grew at the same rate ( $P=0.133$, comparison of the regression slopes, Figure 1) with similar PD time (22.78 h and $27.70 \mathrm{~h}$, respectively). This PD time agrees with previous published data (http://www.nih3t3.com/) for untreated cells.

To understand whether the decrease in cell number observed was due to apoptosis and/or to alterations in the progression through the cell cycle stages, the Annexin V assay and the nuclear DNA content evaluation were used, respectively.

\section{Apoptosis}

Figure 2 reports the fraction of $\mathrm{R} 1$ and $3 \mathrm{~T} 3$ cells positive to Annexin $\mathrm{V}\left(\mathrm{AnV}^{+}\right.$early apoptotic marker), Annexin $\mathrm{V}$ and propidium iodide $\left(\mathrm{AnV}^{+} / \mathrm{PI}^{+}\right.$, late apoptotic marker), or propidium iodide ( $\mathrm{PI}^{+}$, cell death marker) after CYP exposure, expressed as fold change relative to CTR set at 1 .

$\mathrm{AnV}^{+}$and $\mathrm{AnV}^{+} / \mathrm{PI}^{+} \mathrm{R} 1$ cells significantly increased after both $12 \mathrm{~h}$ (3.2- and 2.4-fold, respectively; $\mathrm{P}<0.05)$ and $24 \mathrm{~h}$ (1.6- and 2.2-fold, respectively; $\mathrm{P}<0.05$ ) exposure, when comparted to the CTR population (Figure $2 \mathrm{~A}$ ). At $48 \mathrm{~h}$, only apoptotic $\mathrm{PI}^{+}$cells were detected, with a 1.4 fold-increase $(\mathrm{P}<0.05)$. A second relevant wave of apoptosis was recorded after $72 \mathrm{~h}$ exposure with a 7.7-fold and a 5.3-fold increase of $\mathrm{AnV}^{+}$and $\mathrm{AnV}^{+} / \mathrm{PI}^{+}$cells, respectively (Figure 2A).

After $8 \mathrm{~h}$ exposure, $\mathrm{AnV}^{+}$and $\mathrm{AnV}^{+} / \mathrm{PI}^{+} 3 \mathrm{~T} 3$ cells increased (1.5 and 1.7-fold, respectively, $\mathrm{P}<0.001$ ), while $\mathrm{PI}^{+} 3 \mathrm{~T} 3$ cells decreased (0.6-fold, $\mathrm{P}<0.05)$ compared to CTR (Figure $2 \mathrm{~B}$ ). After $24 \mathrm{~h}$, a further increase $(\mathrm{P}<0.05)$ up to 2.2- and 2.1-fold for $\mathrm{AnV}^{+}$ and $\mathrm{AnV}^{+} / \mathrm{PI}^{+}$cells, respectively, was observed, whereas $\mathrm{PI}^{+}$cells were not significantly different $(\mathrm{P}>0.05)$ when compared to CTR.
A peak (2.2-fold increase, $\mathrm{P}<0.05)$ of cell death was observed after $48 \mathrm{~h}$, whereas at $72 \mathrm{~h}$ exposed cells completely recovered, showing the same degree of early or late apoptosis as that of CTR $(\mathrm{P}>0.05)$ (Figure 2B).

\section{Distribution of cells in the cell cycle phases}

Next, the nuclear DNA content during the different cell cycle phases was evaluated using a one-parametric analysis of PI-stained nuclei.

In R1 CTR cells, the recorded distribution in $\mathrm{G}_{0} / \mathrm{G}_{1}(32 \%)$, in $\mathrm{S}(54 \%)$ and in $\mathrm{G}_{2} / \mathrm{M}(14 \%)$ phases confirms previous findings of our and other groups. ${ }^{30,31}$ When exposed to CYP, the frequency of R1 cells distributed within the three phases of the cell cycle remained unaltered up to $24 \mathrm{~h}$ (Supplementary Table 2). At 48 and $72 \mathrm{~h}$, the frequency of cells in $\mathrm{G}_{0} / \mathrm{G}_{1}$ significantly decreased $(\mathrm{P}<0.001)$, in association with a significant increase of cells in $\mathrm{G}_{2} / \mathrm{M}$ phase (Supplementary Table 2 ), suggesting an activation of a $\mathrm{G}_{2} / \mathrm{M}$ cell cycle block at both time points.

About $67 \%$ of unexposed $3 \mathrm{~T} 3$ cells were in $\mathrm{G}_{0} / \mathrm{G}_{1}$ phase, $14 \%$ in $\mathrm{S}$ phase and $18 \%$ in $\mathrm{G}_{2} / \mathrm{M}$ phase (Supplementary Table 2 and Tai et al..$^{32}$ ). After 8 and $24 \mathrm{~h}$ of CYP exposure the distribution of cells in the different phases of the cell cycle remained unaltered compared to CTR (Supplementary Table 2), instead, at $48 \mathrm{~h}$, the frequency of cells in $\mathrm{G}_{0} / \mathrm{G}_{1}$ increased $(\mathrm{P}<0.001)$ while the frequency of cells in $\mathrm{S}$ and in $\mathrm{G} 2$-phase significantly decreased $(\mathrm{P}<0.001)$ (Supplementary Table 2), suggesting an activation of $\mathrm{G}_{0} / \mathrm{G}_{1}$ block of the cell cycle. The distribution of cells in the three phases returns not significantly different compared to CTR after $72 \mathrm{~h}$ exposure. Then, we determined whether reactive oxygen species (ROS) are induced by CYP. Also, we evaluated whether an antioxidant cellular response is triggered, by analysing the expression of Cat, Sod1, Sod2, Gpxl and Gpx4 genes, which code for major antioxidant proteins against ROS.

\section{ROS production and redox-related gene expression}

A
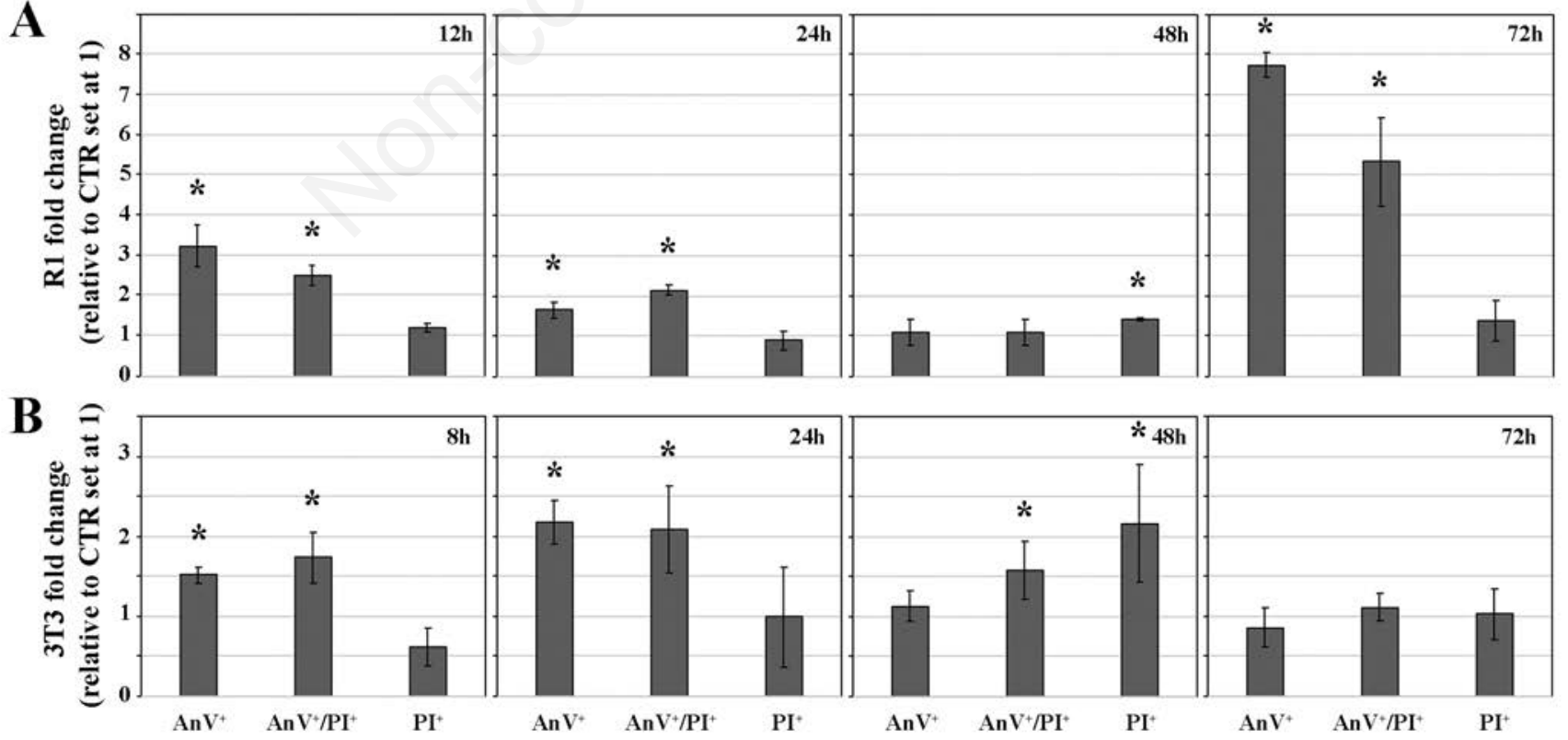

Figure 2. Annexin $\mathrm{V}$ positive $\left(\mathrm{AnV}^{+}\right)$, Annexin $\mathrm{V}$ and propidium iodide positive $\left(\mathrm{AnV}^{+} / \mathrm{PI}^{+}\right)$and propidium iodide positive $\left(\mathrm{PI}^{+}\right)$cells in $\mathrm{R1}(\mathrm{A})$ and $3 \mathrm{~T} 3$ (B) cell lines, detected 8 (3T3), 12 (R1), 24, 48 or $72 \mathrm{~h}$ after CYP exposure. ${ }^{*} \mathrm{P}<0.001$. 


\section{response}

Exposed R1 cells showed 1.2-fold increase $(\mathrm{P}<0.05)$ in ROS production beginning at $24 \mathrm{~h}$ culture. ROS production continues to increase after both 48 and $72 \mathrm{~h}$ (1.3 and 1.6 fold, respectively, $\mathrm{P}<0.05$ ) (Figure $3 \mathrm{~A}$ ). In exposed $\mathrm{R} 1$ cells, ROS production was paralleled by the induction $(\mathrm{P}<0.001)$ of Cat, Sod1, Sod2, and Gpx4 gene expression, at $48 \mathrm{~h}$ culture, and also of Gpxl $(\mathrm{P}<0.05)$ at $72 \mathrm{~h}$ (Figure 3B and Supplementary Table 3).

Compared to CTR, exposed 3T3 cells displayed higher levels of ROS at $24 \mathrm{~h}$ and $48 \mathrm{~h}(1.3-$ and 1.2-fold, respectively; $\mathrm{P}<0.05)$ (Figure $3 \mathrm{~A}$ ), but not at $8 \mathrm{~h}$ and $72 \mathrm{~h}$. Of the five gene transcripts (Cat, Sod1, Sod2, Gpxl and Gpx4) analysed, no difference between CTR and exposed cells was detected within $8 \mathrm{~h}$, whereas, after $24 \mathrm{~h}$, cells displayed significant increase $(\mathrm{P}<0.05)$ of $C a t$ expression and slight, but significant, decrease $(\mathrm{P}<0.05)$ of $G p x 1$ and $\operatorname{Sod} 2$ transcripts. Sod 2 transcripts remained low in exposed cells after $48 \mathrm{~h}$ culture. At $72 \mathrm{~h}$, slight $(\mathrm{P}<0.05)$ Cat and Gpx4 induction was detected (Figure 3B and Supplementary Table 4).

To determine if the detoxification mechanisms, known to be involved in the processes of elimination of environmental toxicants, ${ }^{33}$ were activated in response to CYP exposure, the expression profile of cytochromes P450 Cyplal and Cyplb1 (AHR-regulated of phase I) and Nqo1, Gstal and Ugt1a6 (AHR-regulated of phase II) enzymes was evaluated.

\section{Phase I and phase II gene expression response}

In exposed R1 mESCs, of the two Phase I genes, the level of Cyplal transcripts was similar to CTR at 12 and $72 \mathrm{~h}$ whereas it was lower $(\mathrm{P}<0.05)$ at both 24 and $48 \mathrm{~h}$; Cyplb1 was down regulated $(\mathrm{P}<0.05)$ at 24 and $48 \mathrm{~h}$ but up regulated $(\mathrm{P}<0.001)$ at $72 \mathrm{~h}$ culture. Ugt1a6 Phase II gene was initially down regulated $(\mathrm{P}<0.05)$, but then it was up regulated $(\mathrm{P}<0.001)$ from $24 \mathrm{~h}$ until the end of the culture period. Also up regulated $(\mathrm{P}<0.001)$ were Gstal (from $48 \mathrm{~h}$ ) and Nqol (at $72 \mathrm{~h}$ ) (Figure 4 and Supplementary Table 3).

Compared to CTR, of the five genes analysed, three were upregulated in 3T3 exposed cells: Cyplal $(\mathrm{P}<0.05)$ at $24 \mathrm{~h}$; Ugtla6 $(\mathrm{P}<0.001)$ from $24 \mathrm{~h}$, Gstal $(\mathrm{P}<0.001)$ from $48 \mathrm{~h}$. The expression of the other two genes ( $\mathrm{Cyplbl}$ and $\mathrm{NqO1}$ ) remained unaltered ( $\mathrm{P}>0.01)$ (Figure 4 and Supplementary Table 4).

\section{Pluripotency and germ cell layers gene expression}

When R1 mESCs were exposed to CYP for 12 and $24 \mathrm{~h}$, they displayed a significant reduction $(\mathrm{P}<0.001)$ of Oct-4 and Nanog expression compared to CTR. To the contrary, after $72 \mathrm{~h}$ exposure, for Oct-4, or $48 \mathrm{~h}$ and $72 \mathrm{~h}$ exposure, for Nanog, the expression significantly increases $(\mathrm{P}<0.001)$ (Figure 5A and Supplementary Table 5). The altered expression of two genes of the pluripotency core might influence the differentiation capacity of exposed R1 ESCs. To test whether CYP-exposed mESCs maintain their ability to form the three germ layers, they were differentiated into EBs for
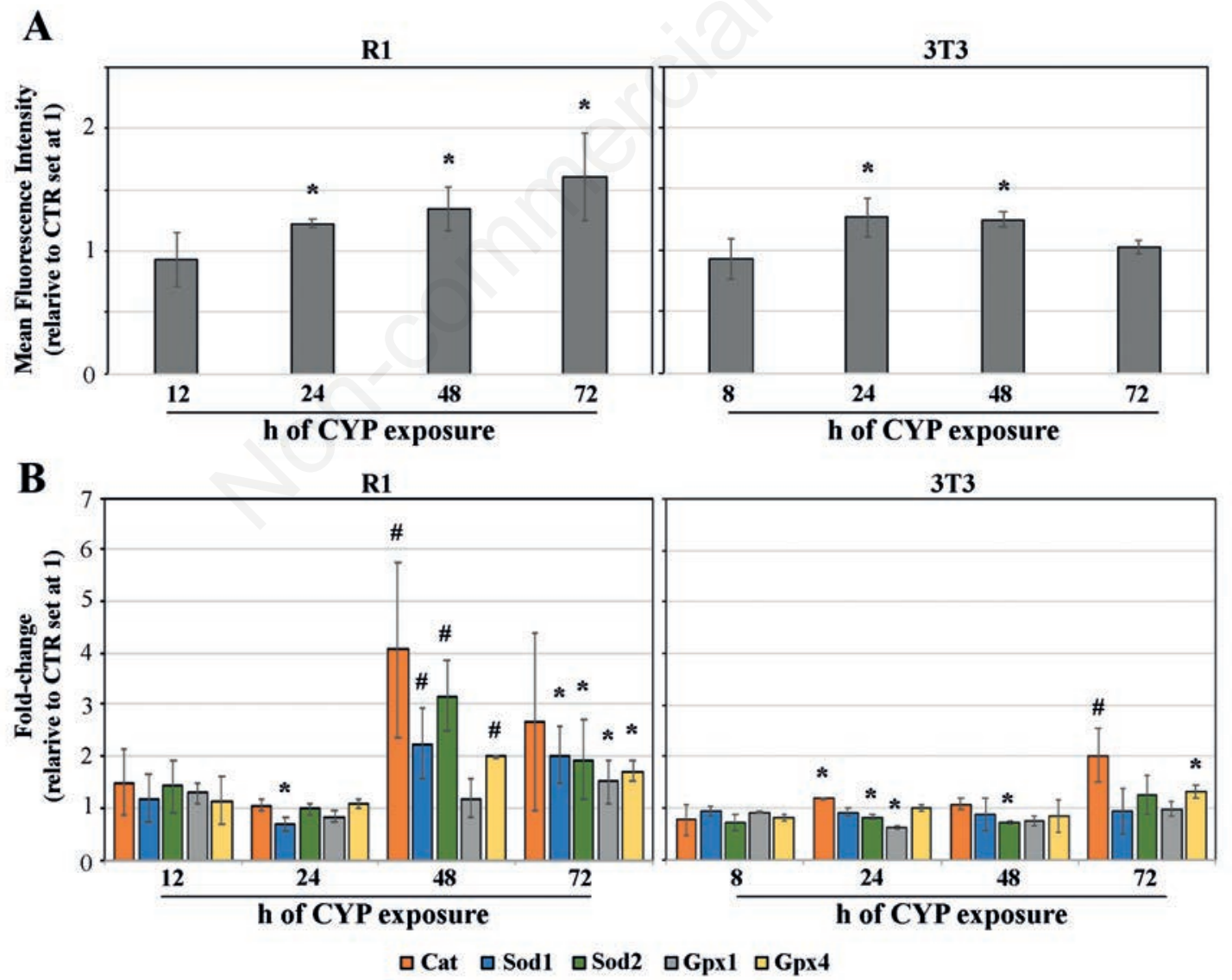

Figure 3. A) ROS content in R1 and 3T3 cell populations. B) Expression profile of Cat, Sod1 and 2 and of Gpx1 and 4 ROS redoxresponse genes, at different time points in the presence of CYP. The expression values of CTR samples were set at 1 for the calculation of the $n$-fold change. Values are expressed as mean $\pm S D$. ${ }^{*} P<0.05 ; \# P<0.001$. 
5 days. As expected, Fgf5, Brachyury, and Foxa2 (markers of the ectoderm, mesoderm and endoderm, respectively) were highly induced in CTR EBs when compared to undifferentiated mESCs (2.3, 60.0 and 5.9-fold change, respectively; data not shown).

CYP-exposed ESCs maintain the ability to form EBs, but displayed altered expression of the markers of three germ layers. Specifically, the expression of $F g f 5$ in EBs obtained from ESCs exposed to CYP for $12 \mathrm{~h}$ and $72 \mathrm{~h}$ is similar to CTR EBs (Figure 5B; Table 6S), whereas it is reduced $(\mathrm{P}<0.001)$ in EBs obtained from ESCs exposed to CYP for 24 and $48 \mathrm{~h}$. The number of Brachyury gene transcripts is significant altered $(\mathrm{P}<0.001)$, either lower or higher (Figure 5B; Supplementary Table 6), in EBs derived from mESCs exposed to CYP when compared to CTR EBs. Foxa2 gene transcripts are significantly $(\mathrm{P}<0.001)$ overexpressed in EBs obtained from CYP-exposed ESCs for 12, 48 and $72 \mathrm{~h}$ (Figure 5B and Table 6S).

\section{Discussion}

The results of this study highlight three main responses of ESCs following exposure to the pyrethroid insecticide cypermethrin: alterations of the i) cell growth kinetics; ii) phase II detoxification genes induction; and iii) expression of the pluripotency and the three germ layers gene markers.

Compared to control, CYP-exposed R1 ESCs display a massive $45 \%$ decrease in number during the first $24 \mathrm{~h}$, followed by proliferation resumption during the remaining culture period. This resumption is characterized by significant longer PD time which contributes to explain the slower growth rate. The activation of a first apoptotic wave, observed soon after 12-24 h exposure, might represent a short-term response, perhaps needed for the elimination of highly damaged cells from the population. It is well known that mESCs undertake facilitated cell death ${ }^{34,35}$ because of the lack of checkpoints controlling the $\mathrm{G}_{1}-\mathrm{S}$ and the intra- $\mathrm{S}^{30,34,36}$ transition

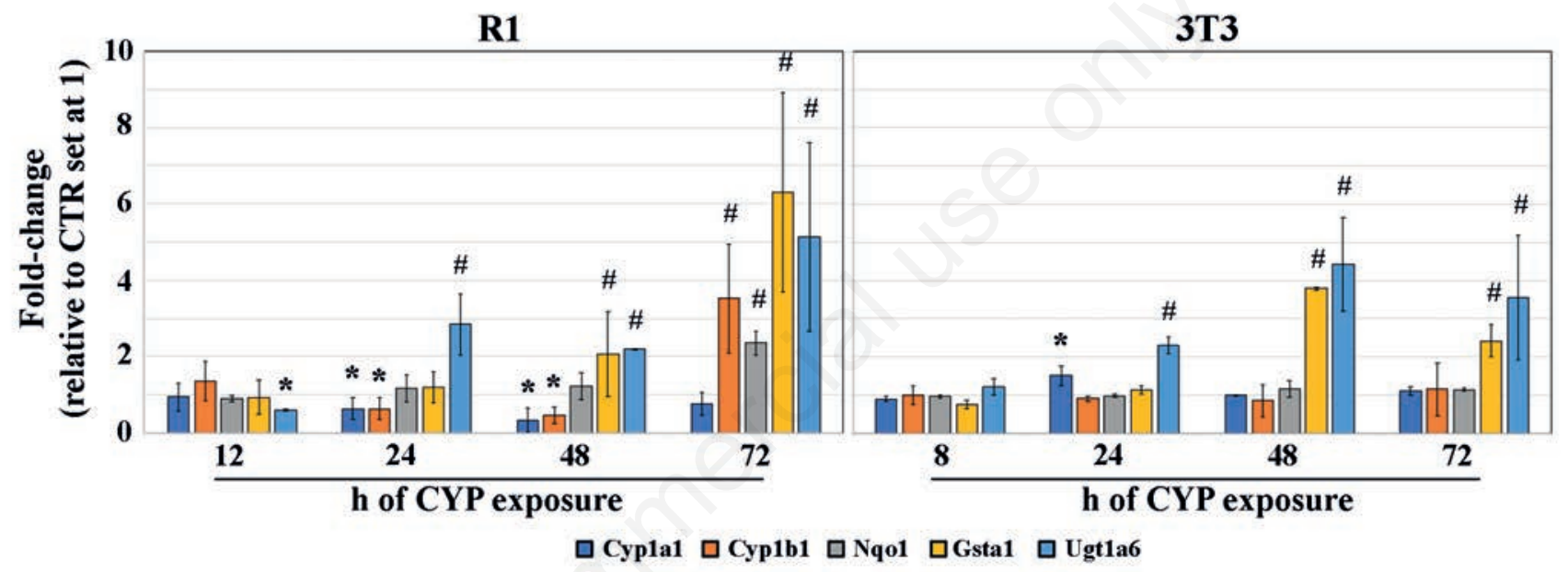

Figure 4. Expression profile of Cyp1a1, Cyp1b1 (Phase I), Nqo1, Gst1 and Ugt1a6 (Phase II) detoxification genes, at different time points in the presence of CYP. The expression values of CTR samples were set at 1 for the calculation of the n-fold change. Values are expressed as mean $\pm \mathrm{SD} .{ }^{*} \mathbf{P}<0.05 ; \# \mathbf{P}<0.001$.
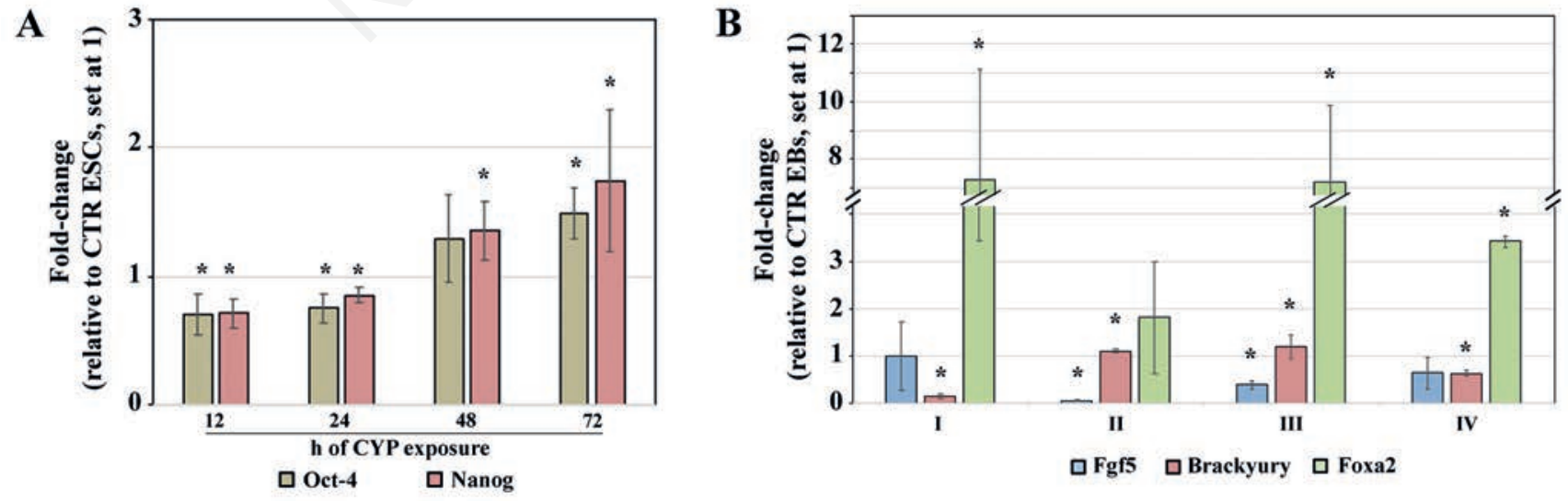

Figure 5. A) Expression profile of Oct-4 and Nanog pluripotency marker genes of ESCs exposed for 12, 24, 48 and $72 \mathrm{~h}$ to CYP; the expression values of CTR ESCs were set at 1 for the calculation of the n-fold change. B) Expression profile of Fgf5, Brachyury and Foxa2, early gene markers of the three germ layers, of EBs obtained from ESCs exposed to CYP for 12 (I), 24 (II), 48 (III) or 72 (IV) $h$. The expression values of CTR EBs were set at 1 for the calculation of the $n$-fold change. 
phases. A second wave of CYP-induced apoptosis is observed at 72 $\mathrm{h}$, when ROS production is further increased, contributing to the elimination of cells arrested in $\mathrm{G}_{2} / \mathrm{M}$ phase at $48 \mathrm{~h}$ and $72 \mathrm{~h}$ exposure, likely those with unrepairable damages. The increase of the production of ROS is also accompanied by the induction, beginning at 48 h CYP treatment, of redox-related Cat, Sod1, Sod2, Gpx1 and Gpx4 genes.

In parallel, CYP exposure also triggers detoxification endogenous mechanisms, ${ }^{37,38}$ with the up-regulation of only one, Cyp $1 b$, of the two phase I genes studied and of phase II Nqo1, Gstal and Ugtla6 genes. Interestingly, phase II induction occurs earlier (beginning at $24 \mathrm{~h}$ ) than that of phase I genes (at $72 \mathrm{~h}$ ). These results highlight a major role, in pluripotent R1 ESCs, of phase II genes in the detoxification of pyrethroids, including $\beta$-cypermethrin, as shown earlier in human hepatocytes ${ }^{39}$ and in zebrafish embryos. ${ }^{40}$ In addition to Cyp 1 b1, we anticipated that the mechanism of detoxification of pyrethroids in undifferentiated stem cells might be mediated by members of the cytochrome P450 family other than Cypla1, such as Cyp9a10. ${ }^{41}$

Interestingly, CYP exposure altered the expression of Oct-4 and Nanog pluripotency genes in ESCs and, when differentiated into EBs, the expression of Fgf5, Brachyury, and Foxa2, early markers of the ectoderm, mesoderm and endoderm germ layers, respectively. Our results highlight, for the first time, that pyrethroids might be able to perturb the inherent characteristics of pluripotency and differentiation capacity of ESCs.

Compared to R1 ESCs, the behaviour of $3 \mathrm{~T} 3$ embryonic fibroblasts to CYP exposure evidences differences to both cell growth kinetics and detoxification response. In fact, these cells display a mild $10 \%$ decrease in cell number within $8 \mathrm{~h}$ exposure, followed by return to a PD time and growth rate comparable, throughout the remaining culture period, to those of control 3T3. The population growth rate appears to be unaffected by cell death, detected by the late apoptotic markers at $48 \mathrm{~h}$ culture, when the $\mathrm{G}_{0} / \mathrm{G}_{1}$ checkpoint is activated. The growth rate recovery observed could also have been facilitated by the early $(24 \mathrm{~h})$ activation of the detoxification phase I (Cypla1) and phase II (Ugtla6) response, the latter (Ugtla6 and Gstal) maintained until the end of the culture period. The increase of ROS production, initiated at $24 \mathrm{~h}$, is no longer detected at the end of the culture period, when only Cat and Gpx4, out of six redox-related genes analysed, are up-regulated.

The results here reported on $3 \mathrm{~T} 3$ cells confirmed previous observations that the metabolism of differentiated cells better tolerates the exposure to toxic molecules, ${ }^{42-44}$ when compared to undifferentiated cells. For example, differentiated SH-SY5Y neuroblastoma cells displayed higher tolerance to all-trans-retinoic acid $^{42}$ or to inhibitors of the electron-transport chain mitochondrial complex I, ${ }^{44}$ when compared to their undifferentiated counterpart. Also, differentiated human intestinal Caco-2 cells were more resistant to some inorganic compounds (i.e., $\mathrm{SiO}_{2}, \mathrm{ZnO}$ ), than the respective undifferentiated population. ${ }^{43}$

In conclusion, this is the first study to describe the adaptive response of pluripotent stem cells of embryonic origin to continuous exposure to CYP, one of the most common and widely used pyrethroid. The results show that R1 ESCs activate oxidative stress-related and detoxification responses, although not sufficient, during the culture period tested, to warrant recovery of the growth rate observed in untreated cells. Also, our study highlights potential detrimental effects of CYP exposure on the differentiation capacity of ESCs into the three germ layers, a pivotal step for the embryo proper formation. These results, obtained using the most robust in vitro model of the ICM, from which the foetus derives, anticipate possible effects exerted by CYP during pre-implantation development.

\section{Acknowledgments}

The authors express their gratitude to CICOPS (University of Pavia), for the fellowship provided to ENA, and to Dr. Giuliano Mazzini for the cytofluorometer analyses.

This work was supported by the Italian Ministry of Education, University and Research (MIUR): Dipartimenti di Eccellenza Programme (2018-2022) - Department of Biology and Biotechnology "Lazzaro Spallanzani", University of Pavia (to PR, CC, MZ and SG) and by the University of Pavia (FRG to $S G$ and MZ).

\section{References}

1. Feo ML, Eljarrat E, Barceló D. Performance of gas chromatography/tandem mass spectrometry in the analysis of pyrethroid insecticides in environmental and food samples. Rapid Commun Mass Spectrom 2011;25:869-76.

2. Yoo M, Lim YH, Kim T, Lee D, Hong YC. Association between urinary 3-phenoxybenzoic acid and body mass index in Korean adults: 1st Korean National Environmental Health Survey. Ann Occup Environ Med 2016;28:1-8.

3. Tang W, Wang D, Wang J, Wu Z, Li L, Huang M, et al. Pyrethroid pesticide residues in the global environment: An overview. Chemosphere 2018;191:990-1007.

4. Gilden RC. Pesticides use in hospitals: health protection, health hazards, and viable alternatives. Nurs Adm Q 2010; 34:320-6.

5. Bhattacharjee S, Fakhruddin AN, Chowdhury MA, Rahman MA, Alam MK. Monitoring of selected pesticides residue levels in water samples of paddy fields and removal of cypermethrin and chlorpyrifos residues from water using rice bran. Bull Environ Contam Toxicol 2012;89:348-53.

6. Choudhury HB, Das KB, Chutia P. Evaluation of pesticide residues in fish tissue samples collected from different markets of Jorhat district of Assam. India. Int J Scient Engin Res 2013; 4:2286-99.

7. Debbab M, El Hajjaji S, Aly HA, Dahchour A, El Azzouzi M, Zrineh A. Cypermethrin residues in fresh vegetables: Detection by HPLC and LC-ESIMS and their effect on antioxidant activity. Mater Environ Sci 2014;5:2257-66.

8. Saillenfait AM, Ndiaye D, Sabaté JP. Pyrethroids: exposure and health effects - an update. Int J Hyg Environ Health 2015; 218:281-92.

9. European Commission. Technical Support for the Impact Assessment of the Review of Priority Substances under Directive 2000/60/EC Substance: Cypermethrin. Entec UK Ltd., Reading; 2011.

10. Manfo FP, Moundipa PF, Déchaud H, Tchana AN, Nantia EA, Zabot MT, Pugeat M. Effect of Agropesticides use on male reproductive function: A study on farmers in Djutitsa (Cameroon). Environ Toxicol 2012;27:423-32.

11. Nantia EA, Manfo TFP, Sonchieu J, Choumessi TA, Bopuwouo RH, Kakwang FI, et al. Effect of agrochemicals use on total phenolic compounds and flavonoid content in aromatic fresh herbs from Santa (Cameroon). Acad J Agricult Res 2017;5:18-27.

12. Uner N, Oruç EO, Canli M, Sevgiler Y. Effects of cypermethrin on antioxidant enzyme activities and lipid peroxidation in liver and kidney of the freshwater fish, Oreochromis niloticus and Cyprinus carpio (L.). Bull Environ Contam Toxicol 2001; 67:657-64.

13. Jin Y, Zheng S, Pu Y, Shu L, Sun L, Liu W, et al. Cypermethrin has the potential to induce hepatic oxidative stress, DNA dam- 
age and apoptosis in adult zebrafish (Danio rerio). Chemosphere 2011a;82:398-404.

14. Jin Y, Wang L, Ruan M, Liu J, Yang Y, Zhou C, et al. Cypermethrin exposure during puberty induces oxidative stress and endocrine disruption in male mice. Chemosphere 2011b;84:124-30.

15. Paravani EV, Simoniello MF, Poletta GL, Zolessi FR, Casco VH. Cypermethrin: Oxidative stress and genotoxicity in retinal cells of the adult zebrafish. Mutat Res Genet Toxicol Environ Mutagen 2018;826:25-32.

16. Paravani EV, Simoniello MF, Poletta GL, Casco VH. Cypermethrin induction of DNA damage and oxidative stress in zebrafish gill cells. Ecotoxicol Environ Saf 2019;173:1-7.

17. Giray B, Gürbay A, Hincal F. Cypermethrin-induced oxidative stress in rat brain and liver is prevented by vitamin E or allopurinol. Toxicol Lett 2001;118:139-46.

18. Huang F, Liu Q, Xie S, Xu J, Huang B, Wu Y, et al. Cypermethrin induces macrophages death through cell cycle arrest and oxidative stress-mediated JNK/ERK signaling regulated apoptosis. Int J Mol Sci 2016;1:e885.

19. Zhou YJ, Huang HR, Zhou J, Wang LQ. Beta-cypermethrin exposure affects female reproduction by enhancing oxidative stress in mice uterine tissue. Regul Toxicol Pharmacol 2018;98:284-90.

20. Jukam, D, Shariati, SAM, and Skotheim, JM. Zygotic genome activation in vertebrates. Dev Cell 2017;42:316-32.

21. Koot YE, Teklenburg G, Salker MS, Brosens JJ, Macklon NS. Molecular aspects of implantation failure. Biochim Biophys Acta 2012;1822:1943-50.

22. Evans MJ, Kaufman MH. Establishment in culture of pluripotential cells from mouse embryos. Nature 1981;292:154-6.

23. Martin GR. Isolation of a pluripotent cell line from early mouse embryos cultured in medi- um conditioned by teratocarcinoma stem cells. Proc Natl Acad Sci USA 1981;78:7634-8.

24. Thomson JA, Itskovitz-Eldor J, Shapiro SS, Waknitz MA, Swiergiel JJ, et al. Embryonic stem cell lines derived from human blastocysts. Science 1998;282:1145-7.

25. Rebuzzini P, Pignalosa D, Mazzini G, Di Liberto R, Coppola A, Terranova N, et al. Mouse embryonic stem cells that survive $\gamma$-rays exposure maintain pluripotent differentiation potential and genome stability. J Cell Physiol 2012;227:1242-9.

26. Rebuzzini P, Martinelli P, Blasco M, Giulotto E, Mondello C. Inhibition of gene amplification in telomerase deficient immortalized mouse embryonic fibroblasts. Carcinogenesis 2007;28:553-9.

27. Rebuzzini P, Fassina L, Mulas F, Bellazzi R, Redi CA, Di Liberto R, et al. Mouse embryonic stem cells irradiated with $\gamma$ rays differentiate into cardiomyocytes but with altered contractile properties. Mutat Res 2013;756:37-45.

28. Rebuzzini P, Cebral E, Fassina L, Redi CA, Zuccotti M, Garagna S. Arsenic trioxide alters the differentiation of mouse embryonic stem cell into cardiomyocytes. Sci Rep 2015; 5:14993.

29. Tamm C, Pijuan Galitó S, Annerén C. A comparative study of protocols for mouse embryonic stem cell culturing. PLoS One 2013;8:e81156.
30. Savatier P, Lapillonne H, Jirmanova L, Vitelli L, Samarut J. Analysis of the cell cycle in mouse embryonic stem cells. Methods Mol Biol 2002;185:27-33.

31. Rebuzzini P, Neri T, Mazzini G, Zuccotti M, Redi CA, Garagna S. Karyotype analysis of the euploid cell population of a mouse embryonic stem cell line revealed a high incidence of chromosome abnormalities that varied during culture. Cytogenet Genome Res 2008;121:18-24.

32. Tai MH, Weng CH, Mon DP, Hu CY, Wu MH. Ultraviolet $\mathrm{C}$ irradiation induces different expression of cyclooxygenase 2 in NIH 3 T3 cells and A431 cells: the roles of COX-2 are different in various cell lines. Int J Mol Sci 2012;13:4351-66.

33. Rushmore TH, Kong AN. Pharmacogenomics, regulation and signaling pathways of phase I and II drug metabolizing enzymes. Curr Drug Metab 2002;3:481-90.

34. Hong Y, Stambrook PJ. Restoration of an absent G1 arrest and protection from apoptosis in embryonic stem cells after ionizing radiation. Proc Natl Acad Sci USA 2004;101:14443-8.

35. Stambrook PJ. An ageing question: do embryonic stem cells protect their genomes? Mech Ageing Dev 2007;128:31-5.

36. Savatier P, Huang S, Szekely L, Wiman KG, Samarut J. Contrasting patterns of retinoblastoma protein expression in mouse embryonic stem cells and embryonic fibroblasts. Oncogene 1994;9:809-18.

37. Omiecinski CJ, Vanden Heuvel JP, Perdew GH, Peters JM. Xenobiotic metabolism, disposition, and regulation by receptors: from biochemical phenomenon to predictors of major toxicities. Toxicol Sci 2011;120:S49-75.

38. Birben E, Sahiner UM, Sackesen C, Erzurum S, Kalayci O. Oxidative stress and antioxidant defense. World Allergy Organ J 2012;5:9-19.

39. Hodgson E. Metabolic interactions of environmental toxicants in humans. Prog Mol Biol Transl Sci 2012;112:349-72.

40. Zhang J, Liu L, Ren L, Feng W, Lv P, Wu W, et al. The single and joint toxicity effects of chlorpyrifos and beta-cypermethrin in zebrafish (Danio rerio) early life stages. J Hazard Mater 2017;334:121-31.

41. Hafeez M, Liu S, Jan S, Shi L, Fernández-Grandon GM, Gulzar A, et al. Knock-down of gossypol-inducing cytochrome P450 genes reduced deltamethrin sensitivity in Spodoptera exigua (Hübner). Int J Mol Sci 2019;20.

42. Cheung YT, Lau WK, Yu MS, Lai CS, Yeung SC, So KF, et al. Effects of all-trans-retinoic acid on human SH-SY5Y neuroblastoma as in vitro model in neurotoxicity research. Neurotoxicology 2009;30:127-35.

43. Gerloff K, Pereira DI, Faria N, Boots AW, Kolling J, Förster I, et al. Influence of simulated gastrointestinal conditions on particle-induced cytotoxicity and interleukin- 8 regulation in differentiated and undifferentiated Caco-2 cells. Nanotoxicology 2013;7:353-66.

44. Khwanraj K, Phruksaniyom C, Madlah S, Dharmasaroja P. Differential expression of tyrosine hydroxylase protein and apoptosis-related genes in differentiated and undifferentiated SH-SY5Y neuroblastoma cells treated with MPP(.). Neurol Res Int 2015;2015:734703.

Received for publication: 12 November 2019. Accepted for publication: 5 February 2020.

This work is licensed under a Creative Commons Attribution-NonCommercial 4.0 International License (CC BY-NC 4.0).

(C) Copyright: the Author(s), 2020

Licensee PAGEPress, Italy

European Journal of Histochemistry 2020; 64:3084

doi:10.4081/ejh.2020.3084 